\title{
Job Satisfaction of Academic Librarians: An Examination of the Relationships between Satisfaction, Faculty Status, and Participation
}

\section{Bonnie Horenstein}

\begin{abstract}
This study examines job satisfaction of academic librarians as it relates to faculty status and participation of librarians in library planning and decision making, university academic affairs, and professional library activities. A questionnaire was distributed to librarians in 300 United States academic libraries at a random sample of universities and colleges in the United States with enrollments exceeding 2,000 students. An SPSS (Statistical Package for the Social Sciences) data analysis of 638 responses focused on job satisfaction of three groups of librarians: librarians with no faculty status or rank; librarians with either faculty status or rank, but not both; and librarians with both faculty status and rank. Academic librarians with both faculty status and rank were more satisfied than librarians in the other two groups. They also perceived themselves as more involved in library planning and decision making, more frequently consulted, better informed about matters affecting the library, and more involved in the university. The best predictors of overall satisfaction were perception of participation, salary, and possession of academic rank.
\end{abstract}

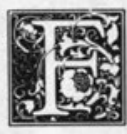

aculty status for academic librarians is a pervasive topic in library literature and an issue of continuing debate. This study explores job satisfaction of academic librarians and its relationship to faculty status of librarians. Are faculty librarians more satisfied than those who lack faculty positions or those with hybrid status? Do librarians with faculty status participate more in library planning, decision making, university activities, and professional activities beyond the university? Do faculty librarians per- ceive a greater level of participation than other librarians? Is participation related to satisfaction? These are the pertinent questions addressed here.

This study examines job satisfaction as it relates to faculty status of librarians, and participation of librarians in library planning and decision making, university academic affairs, and professional library activities. Information about job satisfaction in general for academic librarians, including a profile of satisfactory and unsatisfactory aspects of the profession, was also sought. Some of the

Bonnie Horenstein is Coordinator of Catalog Services and Assistant Professor of Library Science at Adelphi University, Garden City, New York 11530. The author would like to thank Gary Zaslow for his assistance in the statistical analysis, the Derner Institute for Advanced Psychological Studies at Adelphi University for their guidance, and Reuben Molloy for his assistance in the setup of the data. 
variables emerging from previous research, which will be discussed in the next section, "Literature Review," were tested in the context of librarianship in the 1990s.

The survey was aimed at the rankand-file professional academic librarian. Deans, associate deans, and directors were excluded. Part-time librarians were also excluded. Since responsibilities, participation, and expectations of librarians in very small institutions can be quite different from those in larger settings, institutions with enrollments of under 2,000 students were excluded.

The population studied was full-time librarians in universities and colleges in the United States with enrollments of 2,000 or more students as listed in Patterson's American Education. Public and private institutions were included.

\section{LITERATURE REVIEW}

A review of library literature revealed little information relating job satisfaction to faculty status of librarians. While faculty status of librarians receives abundant attention in the literature of librarianship, there are no empirical studies of its effect on job satisfaction.

Faculty status might be regarded as a key benefit to academic librarians and assumed to positively affect job satisfaction. Yet, the reverse has also been hypothesized. Harold V. Hosel argued that faculty status increases role conflict and role ambiguity, both components of role stress, which might thereby reduce job satisfaction. He suggested the need for further research in this area to test his inferences. ${ }^{\prime}$

Although job satisfaction has received some attention in library literature, it has often been related to participative management style. Participative management refers to a style of management that stresses the importance of involving workers in management decision making. ${ }^{2}$ In a landmark study involving twenty-two academic libraries in the 1970s, Maurice P. Marchant identified participative management style as the strongest predictor of librarians' job satisfaction. ${ }^{3}$ Marchant's findings were tested and supported by
Dale Susan Bengston and Dorothy Shields in a single-institution study of Brigham Young University. ${ }^{4}$ Management style was again found to be a strong predictor of librarians' job satisfaction. Several other studies have explored job satisfaction of academic librarians related to gender of the librarian. ${ }^{5}$ In other studies, job satisfaction of library workers (professional and clerical) was related to the unit of the library where they worked, with contradictory findings. While Steven Seokho Chwe found no significant differences between overall satisfaction of reference librarians and catalogers in university libraries and George P. D'Elia found no differences between satisfaction of public and technical services librarians, Beverly P. Lynch and Jo Ann Verdin found that reference librarians were more satisfied..$^{6,7,8}$

In a recent study, Mohammed H. Mirfakhrai compared job satisfaction of academic librarians in large and small-size university libraries, finding higher levels of overall satisfaction among librarians in small libraries. ${ }^{9}$ Leigh Estabrook, Chloe Bird, and Frederick L. Gilmore examined the relationship of technological change to job satisfaction of librarians and support staff, finding that sources of job satisfaction-namely, income, social interaction, and discretion over workhave not changed with automation. ${ }^{10}$ In "A Review of Faculty Status Surveys, 1971-1984," Janet Krompart and Clara DiFelice noted a lack of information about "what librarians experience and think" because surveys are usually directed to library directors and only about 25 percent "queried librarians." 11

\section{METHODOLOGY}

The survey instrument was a fiftyfive-item questionnaire written by the author (see appendix). Several standard instruments for measuring job satisfaction were considered but deemed inappropriate for the purpose of this research. Therefore, an instrument was developed specifically for this study.

The first section of the questionnaire elicited background information, such as faculty status, rank, salary, tenure and 
other benefits, gender, and department of respondent. Faculty status and faculty rank were assumed to be either institutionally granted or not. Faculty rank was understood by the author to mean instructor, assistant professor, associate professor, and professor. The second section of the questionnaire gathered information about the participation and perceived participation of the responding librarian in library planning and decision making, university academic structures, and professional library activities. The final section of the questionnaire focused on job satisfaction, including twenty-one aspects as well as "overall satisfaction" to which librarians responded on a scale of 1 to 5 . A checkoff format was chosen for the questionnaire in an effort to minimize the time respondents needed to complete it and to maximize the probability that the questionnaires would be returned.

The questionnaires were mailed to the dean or director of a random sample of 300 libraries from the population defined above. Five copies were included in an effort to broaden the number of respondents (without increasing postage) and to provide more than one point of view from the library. In a cover letter from the author, each dean or director was asked to distribute the questionnaires to the first five librarians on his/her alphabetical roster of full-time professional staff. The questionnaire was distributed in April 1991. Two weeks were allowed for returns.

\section{RESPONSE}

Six hundred and forty of the 1,500 questionnaires distributed were returned, yielding a return rate of 42.6 percent. The response was much higher than anticipated. An extremely low budget had precluded providing return postage, or even a printed questionnaire. Therefore, the high response rate suggested the topic captured the interest of the sample population. Attached comments, anecdotes, and lengthy personal statements reinforced the author's perception that the questionnaire was positively received and generated high interest among the targeted librarians.
Several of the receiving libraries did not cooperate in the distribution of questionnaires, citing tight budgets, a clutter of questionnaires, and, according to one library, irrelevance to its mission.

\section{DATA ANALYSIS}

The responses from 638 questionnaires were coded and included in an SPSS data analysis. Two of the questionnaires out of the 640 received were excluded from analysis because the respondents were administrative or part-time staff.

Three groups of librarians were identified based on responses to question 1 (Do you have faculty status?) and question 2 (Do you have faculty rank?) on the questionnaire. Six hundred and thirty- one respondents had answered both questions 1 and 2. Group 1 included librarians with no faculty status or rank ( $n=190)$; Group 2 included librarians with either faculty status or rank, but not both $(n=112)$; and Group 3 included librarians with both faculty status and rank $(n=329)$.

The data analysis was structured to yield the following information:

- Profile of respondents, including education, years of service, salary, and other background data. Number and percent of librarians who report faculty status and rank as defined in Groups 1-3.

- Job satisfaction of respondents (Questions 33-54). Is it different for Groups 1,2 , and 3 ?

- Profile of aspects of academic librarianship most/least satisfying to librarians.

- Relationship of participation to job satisfaction? Is participation different for Groups 1, 2, and 3?

- Relationship of job satisfaction to respondent's years in the profession, salary, gender, department, tenure status, rank, or other background data.

- Frequency of response for each question.

\section{PROFILE OF RESPONDENTS}

What were some of the general characteristics of the responding librarians? Of the responding librarians $(n=636), 67.5$ percent indicated they had faculty status; 32.5 percent did not. Faculty rank was held by 54.5 percent and 45.5 percent did 
not have rank ( $n=637$ ). Both rank and status were held by 52.2 percent.

A large proportion of the librarians (38.3 percent) $(n=630)$ had more than fifteen years of experience in professional positions. Salaries were middle-range with 51.2 percent earning between $\$ 25,000$ to $\$ 35,000$ per year $(n=629)$. Publication as a requirement by their institutions was cited by 28.6 percent of the responding librarians and 29 percent indicated there was no publication required $(n=610)$.

Table 1 summarizes demographic data for the respondents.

\section{JOB SATISFACTION OF RESPONDENTS}

The aspects of job satisfaction listed on the questionnaire were derived from studies of job satisfaction and included both intrinsic and extrinsic measures. Intrinsic items are inherent in the activity, such as assigned duties or management style, while extrinsic items are external to the work, such as salary and benefits.

Librarians responded to all of the satisfaction items on a 5-point scale, where 1 is unsatisfactory, 3 is satisfactory, and 5 is highly satisfactory. Overall satisfaction was assessed in two ways. Question 54, "overall satisfaction with your job," queried the librarians' overall satisfaction directly. In addition, the sum of responses to items 33 to 53 , which related to the various aspects of job satisfaction, was calculated for each respondent as a measure of overall job satisfaction. In cases where an individual omitted an item, the sum was not calculated.

A factor analysis was performed on the satisfaction items. Factor analysis is used in statistics to identify a small number of factors underlying complex phenomena. ${ }^{12}$ The satisfaction items all loaded onto a single factor, showing they were in fact measuring the same phenomenon.

Reliability analysis was performed on the sum of questions 33 to 53 to test how reliable the sum served as a measure of overall satisfaction. It was found to be reliable (alpha $=.9290)$ and is considered a better measure of satisfaction than the single question 54 , overall satisfaction.
Librarians reported above satisfactory levels of overall job satisfaction. Question 54, "overall satisfaction with your job," resulted in a mean response of 3.52 $(n=631 / s d=.93)$. Overall satisfaction as measured by the sum of 33 to 53 resulted in a mean of $68.01(n=549 / \mathrm{sd}=14.55)$. In this category, a mean value of 63 indicates "satisfactory" and a value of 105 indicates "highly satisfactory." Thus librarians responded a little more positively to the single question "overall satisfaction" than the sum of their responses to all of the items.

Aspects of librarians' position that were most satisfactory to the total group in rank order were relationship with library users, relationship with peers, assigned duties, and opportunities for variety. Aspects of their position that librarians in the total group found least satisfactory in rank order were opportunities for promotion or other advancement, other recognition for accomplishments, and salary.

Approximately twenty librarians voiced their feelings about their jobs with attached personal statements or comments. On the positive side, individual librarians spoke favorably about the autonomy and control they enjoyed in their work and in such matters as governance, evaluation, hiring and retention, good relations with colleagues and staff, and involvement in decision-making processes. On the negative side, librarians complained about low salaries, poor raises, lack of private office space, negative budgetary impacts (such as reduced staffing and greater workloads), poorly articulated promotion standards, lack of opportunity for meaningful participation, poor management, and department-headdominated decision-making structures.

Table 2 summarizes satisfaction of the total group with the various aspects of their jobs.

In order to examine the relationship of faculty status to job satisfaction, analysis of variance was performed to determine the satisfaction of Groups 1, 2, and 3 to each of the satisfaction items (Questions 33 to 54 and the sum of 33 to 53). When significant differences among the groups 
TABLE 1

DEMOGRAPHIC DATA OF RESPONDENTS

\begin{tabular}{|c|c|c|c|c|c|}
\hline & & $\begin{array}{c}\text { Group } 1 \\
\mathrm{n}=190\end{array}$ & $\begin{array}{c}\text { Group } 2 \\
\mathrm{n}=112\end{array}$ & $\begin{array}{c}\text { Group } 3 \\
n=329\end{array}$ & $\begin{array}{c}\text { Total } \\
\mathrm{n}=631\end{array}$ \\
\hline Status & $\begin{array}{l}\text { yes } \\
\text { no }\end{array}$ & $\begin{array}{r}0 \\
100\end{array}$ & $\begin{array}{l}86.6 \\
13.4\end{array}$ & $\begin{array}{r}100 \\
0\end{array}$ & $\begin{array}{l}67.5 \\
32.5\end{array}$ \\
\hline Rank & $\begin{array}{l}\text { yes } \\
\text { no }\end{array}$ & $\begin{array}{r}0 \\
100\end{array}$ & $\begin{array}{l}13.4 \\
86.6\end{array}$ & $\begin{array}{r}100 \\
0\end{array}$ & $\begin{array}{l}54.5 \\
45.5\end{array}$ \\
\hline Sabbaticals & $\begin{array}{l}\text { yes } \\
\text { no }\end{array}$ & $\begin{array}{l}13.2 \\
86.8\end{array}$ & $\begin{array}{l}70.8 \\
29.2\end{array}$ & $\begin{array}{l}79.1 \\
20.9\end{array}$ & $\begin{array}{l}57.9 \\
42.1\end{array}$ \\
\hline Tenure eligibility & $\begin{array}{l}\text { yes } \\
\text { no }\end{array}$ & $\begin{array}{l}12.4 \\
87.6\end{array}$ & $\begin{array}{l}54.1 \\
45.9\end{array}$ & $\begin{array}{l}84.7 \\
15.3\end{array}$ & $\begin{array}{l}57.5 \\
42.5\end{array}$ \\
\hline Grants eligibility & $\begin{array}{l}\text { yes } \\
\text { no }\end{array}$ & $\begin{array}{l}25.7 \\
74.3\end{array}$ & $\begin{array}{l}79.4 \\
20.6\end{array}$ & $\begin{array}{l}87.1 \\
12.9\end{array}$ & $\begin{array}{l}67.5 \\
32.5\end{array}$ \\
\hline 10-month work year or less & $\begin{array}{l}\text { yes } \\
\text { no }\end{array}$ & $\begin{array}{r}6.0 \\
94.0\end{array}$ & $\begin{array}{l}16.8 \\
83.2\end{array}$ & $\begin{array}{l}29.3 \\
70.7\end{array}$ & $\begin{array}{l}20.0 \\
80.0\end{array}$ \\
\hline Tenured & $\begin{array}{l}\text { yes } \\
\text { no }\end{array}$ & $\begin{array}{l}28.8 \\
71.2\end{array}$ & $\begin{array}{l}45.0 \\
55.0\end{array}$ & $\begin{array}{l}55.5 \\
44.5\end{array}$ & $\begin{array}{l}49.8 \\
50.2\end{array}$ \\
\hline Years as a professional librarian & $\begin{array}{l}0-3 \\
4-9 \\
10-15 \\
\text { over } 15\end{array}$ & $\begin{array}{l}21.6 \\
25.3 \\
22.6 \\
24.1\end{array}$ & $\begin{array}{r}8.1 \\
26.1 \\
23.4 \\
19.5\end{array}$ & $\begin{array}{l}14.9 \\
24.3 \\
19.5 \\
56.4\end{array}$ & $\begin{array}{l}15.7 \\
24.9 \\
21.1 \\
38.3\end{array}$ \\
\hline $\begin{array}{l}\text { Salary under } 25,000 \\
25,000-30,000 \\
31,000-35,000 \\
36,000-40,000 \\
41,000-45,000 \\
\text { over } 45,000\end{array}$ & & $\begin{array}{r}27.0 \\
34.4 \\
21.7 \\
9.5 \\
5.8 \\
1.6\end{array}$ & $\begin{array}{r}18.8 \\
28.6 \\
22.3 \\
17.0 \\
5.4 \\
8.0\end{array}$ & $\begin{array}{r}14.9 \\
26.5 \\
22.0 \\
14.6 \\
12.5 \\
9.5\end{array}$ & $\begin{array}{r}19.2 \\
29.3 \\
21.9 \\
13.5 \\
9.2 \\
6.8\end{array}$ \\
\hline \multicolumn{6}{|c|}{$\begin{array}{l}\text { Publication requirement for promotion, } \\
\text { tenure, or other advancement }\end{array}$} \\
\hline None & & 54.5 & 38.0 & 12.0 & 29.0 \\
\hline Publication encouraged & & 32.6 & 36.1 & 38.9 & 36.6 \\
\hline Some publication required & & 7.3 & 14.8 & 30.9 & 21.1 \\
\hline Substantial record of publicati & equired & .6 & 3.7 & 12.7 & 7.5 \\
\hline Other & & 5.1 & 7.4 & 5.5 & 5.8 \\
\hline \multicolumn{6}{|l|}{ Academic rank held } \\
\hline Instructor & & .7 & 11.1 & 19.3 & 13.4 \\
\hline Assistant professor & & .7 & 13.1 & 45.9 & 29.2 \\
\hline Associate professor & & 3.0 & 11.1 & 24.5 & 16.9 \\
\hline Professor & & 0 & 5.1 & 4.3 & 3.4 \\
\hline Other & & 95.6 & 58.6 & 5.8 & 36.7 \\
\hline \multicolumn{6}{|l|}{ Department } \\
\hline Acquisitions & & 5.9 & 5.4 & 7.0 & 6.4 \\
\hline Reference & & 47.3 & 47.3 & 42.2 & 44.7 \\
\hline Automated systems & & 5.9 & 5.4 & 5.2 & 5.4 \\
\hline Cataloging & & 14.9 & 18.8 & 15.6 & 15.9 \\
\hline Serials & & 4.3 & 1.8 & 4.9 & 4.1 \\
\hline Other & & 21.8 & 21.4 & 25.1 & 23.4 \\
\hline \multicolumn{6}{|l|}{ Gender } \\
\hline Male & & 27.8 & 24.5 & 29.5 & 28.1 \\
\hline Female & & 72.2 & 75.5 & 70.2 & $\begin{array}{r}71.7 \\
\text { ontinu }\end{array}$ \\
\hline
\end{tabular}


TABLE 1 (continued)

DEMOGRAPHIC DATA OF RESPONDENTS

\begin{tabular}{lrrrr}
\hline & $\begin{array}{c}\text { Group 1 } \\
\mathrm{n}=190\end{array}$ & $\begin{array}{c}\text { Group 2 } \\
\mathrm{n}=112\end{array}$ & $\begin{array}{c}\text { Group 3 } \\
\mathrm{n}=329\end{array}$ & $\begin{array}{c}\text { Total } \\
\mathrm{n}=631\end{array}$ \\
\hline Education & & & & \\
M.L.S. & 70.7 & 50.9 & 48.3 & 55.5 \\
Additional master's & 23.4 & 37.5 & 41.0 & 35.1 \\
Ph.D. & 3.7 & 6.3 & 3.0 & 3.8 \\
Other & 2.1 & 5.4 & 7.6 & 5.6 \\
\hline
\end{tabular}

TABLE 2

ASPECTS OF LIBRARIANSHIP RANKED FROM MOST

SATISFACTORY TO LEAST BASED ON RESPONSES OF TOTAL GROUP

\begin{tabular}{ll}
\hline Satisfaction with... & $\begin{array}{c}\text { Mean } \\
\text { (Total) }\end{array}$ \\
\hline Relationship with library users & 4 \\
$\begin{array}{l}\text { Relationship with peers } \\
\text { Assigned duties }\end{array}$ & 3.88 \\
$\begin{array}{l}\text { Opportunities for variety } \\
\text { Opportunities to use your own }\end{array}$ & 3.74 \\
$\quad$ judgment & 3.73 \\
$\begin{array}{l}\text { Opportunities for independence } \\
\text { Opportunities to use your }\end{array}$ & 3.63 \\
$\quad$ abilities, education, training & 3.63 \\
$\begin{array}{l}\text { Opportunites for professional } \\
\text { participation }\end{array}$ & 3.48 \\
$\begin{array}{l}\text { Opportunities for challenge or } \\
\text { creativity }\end{array}$ & 3.44 \\
$\begin{array}{l}\text { Relationship with library } \\
\text { administration }\end{array}$ & 3.29 \\
$\begin{array}{l}\text { Working conditions } \\
\text { Benefits }\end{array}$ & 3.16 \\
$\begin{array}{l}\text { Workload } \\
\text { Opportunities to partcipate in } \\
\text { library planning and decision } \\
\text { making }\end{array}$ & 2.90 \\
$\begin{array}{l}\text { Opportunities for university } \\
\text { participation }\end{array}$ & 2.89 \\
$\begin{array}{l}\text { Management's style } \\
\text { Relationship with university } \\
\text { administration }\end{array}$ & 2.83 \\
$\begin{array}{l}\text { Status of librarians at your } \\
\text { institution }\end{array}$ & 2.80 \\
$\begin{array}{l}\text { Oplary } \\
\text { other recomplishments advancement }\end{array}$ & 2.70 \\
\hline & 2.68 \\
\hline
\end{tabular}

were found, Duncan tests were applied. Duncan's multiple range test is one of a number of tests used in statistics to compare all possible pairs of group means. ${ }^{13}$ The test is used here to compare the groups and find out how they are different from each other.

\section{FACULTY STATUS/RANK AND JOB SATISFACTION}

A positive relationship was found between faculty status/rank and job satisfaction. Significant differences in satisfaction were found among the groups of respondents. Librarians with faculty rank and status (Group3) reported significantly higher levels of overall satisfaction (Question 54) than librarians in Groups 1 or 2. When overall satisfaction was measured by the sum of responses to all of the satisfaction items, librarians in Group 3 also had markedly higher levels of satisfaction than those in Groups 1 or 2.

Librarians in Group 3 were more satisfied with many of the aspects of their jobs than librarians in the hybrid group (rank/no status or status/no rank) or in the group with no rank or status. Significant differences occurred in fourteen of the twenty-three items considered.

Table 3 summarizes the data for satisfaction variables where significant differences were found among the groups. As the significance level approached 0 , and the F ratio increased, the more reliable the differences were among the groups noted in the last column. Group differences notation may be interpreted as follows: $3>1,2$ indicates Group 3 had higher levels of satisfaction than Groups 1 or $2 ; 3>2>1$ indicates Group 3 had higher levels of satisfaction than Group 2 and Group 2 had higher levels than Group $1 ; 3>12>1$ indicates both Groups 3 and 2 had higher 
TABLE 3

SATISFACTION RELATED TO FACULTY STATUS VARIABLES WITH SIGNIFICANT DIFFERENCES AMONG GROUPS

\begin{tabular}{|c|c|c|c|c|c|c|c|}
\hline Variable & $\begin{array}{l}\text { Mean } \\
\text { (Total) }\end{array}$ & mGRP1 & mGRP2 & mGRP3 & Signif. & F Ratio & $\begin{array}{c}\text { Group } \\
\text { Difference }\end{array}$ \\
\hline $\begin{array}{l}\text { Relation with library } \\
\text { administration }(n=625)\end{array}$ & 3.28 & 3.39 & 3.28 & 3.52 & .0301 & 3.52 & $3>2$ \\
\hline $\begin{array}{l}\text { Relation with university } \\
\text { administration }(n=614)\end{array}$ & 2.83 & 2.60 & 2.73 & 2.99 & .0001 & 9.27 & $3>2,1$ \\
\hline Status of librarians $(n=622)$ & 2.80 & 2.34 & 2.63 & 3.12 & .0000 & 30.33 & $3>2>1$ \\
\hline Salary $(n=622)$ & 2.69 & 2.22 & 2.58 & 2.99 & .0000 & 25.46 & $3>2>1$ \\
\hline Benefits $(n=627)$ & 3.15 & 2.71 & 3.18 & 3.39 & .0000 & 22.47 & $\begin{array}{l}3>1 \\
2>1\end{array}$ \\
\hline $\begin{array}{l}\text { Opportunities for promotion } \\
\text { (n=627) }\end{array}$ & 2.66 & 2.28 & 2.55 & 2.91 & .0000 & 20.24 & $3>2>1$ \\
\hline $\begin{array}{l}\text { Other recognition for } \\
\text { accomplishments }(n=621)\end{array}$ & 2.68 & 2.40 & 2.63 & 2.85 & .0000 & 10.95 & $3>1$ \\
\hline $\begin{array}{l}\text { Opportunities to participate } \\
\text { in library planning and } \\
\text { decision making }(n=628)\end{array}$ & 2.90 & 2.76 & 2.77 & 3.02 & .0253 & 3.70 & $3>1$ \\
\hline $\begin{array}{l}\text { Opportunities for university } \\
\text { participation }(n=626)\end{array}$ & 2.89 & 2.30 & 3.04 & 3.17 & .0000 & 45.73 & $\begin{array}{l}3>1 \\
2>1\end{array}$ \\
\hline $\begin{array}{l}\text { Opportunities for } \\
\text { professional participation } \\
(\mathrm{n}=625)\end{array}$ & 3.48 & 3.40 & 3.33 & 3.57 & .0311 & 3.49 & $3>1,2$ \\
\hline $\begin{array}{l}\text { Opportunities for challenge } \\
\text { or creativity }(n=625)\end{array}$ & 3.44 & 3.35 & 3.18 & 3.59 & .0017 & 6.42 & $3>1,2$ \\
\hline $\begin{array}{l}\text { Opportunities for variety } \\
\qquad(\mathrm{n}=629)\end{array}$ & 3.73 & 3.73 & 3.53 & 3.80 & .0560 & 2.90 & $3>2$ \\
\hline $\begin{array}{l}\text { Overall (Question 54) } \\
\quad(n=624)\end{array}$ & 3.52 & 3.42 & 3.40 & 3.62 & .0252 & 3.70 & $3>1,2$ \\
\hline $\begin{array}{l}\text { Overall (sum } 33 \text { to } 53) \\
(n=592)\end{array}$ & 68.03 & 64.04 & 65.74 & 71.13 & .0000 & 14.34 & $3>1,2$ \\
\hline
\end{tabular}

levels than Group 1, but Group 3 did not have higher levels than Group 2.

The most striking differences occurred among the groups in their satisfaction with opportunities for university participation, status of librarians at their institution, salary, benefits, and opportunities for promotion or other advancement. In all cases, Group 3 had significantly higher levels of satisfaction than one or both of the other groups.

No significant differences occurred among the groups in their satisfaction with assigned duties, working conditions, workload, management style, relation with peers, relation with library users, opportunities for independence, or opportunities to use your own judgment.

\section{PARTICIPATION}

To what extent do academic librarians participate in library planning and decision making, university academic affairs, and professional activities beyond their institution? Participation of librarians was assessed in several areas of the questionnaire. The extent of actual participation in teaching, attending meetings of the library or university, and professional membership and activity beyond the university was queried in Questions 16 to 20 . The presence of a formal library planning and decisionmaking structure and the degree to which librarians were meaningfully consulted were addressed in Questions 21 to 
TABLE 4

ACTUAL PARTICIPATION BY GROUP

\begin{tabular}{ll}
\hline & $\begin{array}{c}\text { Group } \\
\text { Differences }\end{array}$ \\
\hline $\begin{array}{l}\text { Teaching hours per year } \\
\text { Library meetings per week }\end{array}$ & None \\
$\begin{array}{c}\text { University meetings per week } \\
\text { Number of library association } \\
\text { memberships }\end{array}$ & $3>2>1$ \\
$\begin{array}{c}\text { Number of professional } \\
\text { meetings attended per year }\end{array}$ & None \\
$\begin{array}{c}\text { Sum of above (Questions } \\
\text { 16-20) }\end{array}$ & $3>1$ \\
$\begin{array}{c}\text { Model of library planning } \\
\text { Regular meetings of } \\
\text { professional'staff }\end{array}$ & None \\
$\begin{array}{c}\text { Presence of library planning } \\
\text { group }\end{array}$ & $3>1$ \\
$\begin{array}{c}\text { Who serves on planning } \\
\text { group? }\end{array}$ & None \\
$\begin{array}{c}\text { Are recommendations } \\
\text { generally implemented? }\end{array}$ & None \\
\hline
\end{tabular}

25. Librarians' perception of their participation was measured on a 4-point scale in Questions 26 to 31 . A single score for perceived participation was calculated for each librarian by adding the responses to Questions 26 to 31 in cases where all questions were answered. This is referred to in this paper as "overall perceived participation."

Questions 26 to 31 were constructed to measure perceived participation. A factor analysis was performed on Questions 26 to 31 . The factor analysis revealed that these questions loaded on to two different factors. It was assumed from this analysis that there are two factors involved in perceived participation. Four variables (Questions 26 to 29) were found to correlate highly with each other and all to load onto a single factor. Since these questions were measuring the same factor, a sum was also attained in cases where all four questions were answered.

\section{PARTICIPATION AND FACULTY STATUS}

Analysis of variance was performed to determine if there were differences in how the groups responded. When signif- icant differences occurred, Duncan tests were applied.

There were no significant differences in how the groups responded to the questions on teaching hours, amount of library and professional meetings attended, library association membership, or the questions relating to a formal library planning group. The model of library planning and decision making, explicitly whether it provided a low or high degree of participation by librarians, did not differ significantly among the groups.

Librarians with faculty status and rank attended more university meetings than the nonfaculty or hybrid groups. They were also more likely to have regular meetings of the professional staff than were nonfaculty librarians. Responses to Questions 16 to 20 were recoded to low, medium, and high values for the purpose of attaining a sum. The overall time spent in teaching, attending meetings of the library, university, and professional organizations as measured by this sum was higher among faculty librarians than nonfaculty librarians. This may be due to their higher participation in the university, a common requirement for faculty librarians.

Differences between the groups in actual participation are summarized in table 4.

Although differences occurred among the groups in only two of the categories of actual participation, librarians with faculty status and rank perceive themselves as more participatory than the other groups.

Faculty librarians felt more involved in library planning and decision making, more consulted, more informed by the administration about matters affecting the library, and more involved in the university than other librarians. In overall perceived participation all of the groups were different, with faculty librarians perceiving the greatest level and nonfaculty librarians perceiving the least.

The differences between the groups are summarized in table 5 .

In each case, librarians with faculty status and rank (Group 3) scored significantly higher than Groups 1 and/or 2. No significant differences occurred among the 
TABLE 5

PERCEIVED PARTICIPATION BY GROUP

\begin{tabular}{|c|c|c|c|c|c|c|c|}
\hline & $\begin{array}{l}\text { Mean* } \\
\text { (Total) }\end{array}$ & mGRP1 & mGRP2 & mGRP3 & Signif. & $\begin{array}{c}\mathbf{F} \\
\text { Ratio }\end{array}$ & $\begin{array}{l}\text { Group } \\
\text { Diff. }\end{array}$ \\
\hline $\begin{array}{l}\text { Involved in library planning } \\
\text { and decision making } n=628\end{array}$ & 2.68 & 2.57 & 2.56 & 2.77 & .0127 & 4.39 & $3>2,1$ \\
\hline Consulted $n=623$ & 3.10 & 3.00 & 2.99 & 3.19 & .0186 & 4.01 & $3>2,1$ \\
\hline Informed $n=626$ & 2.92 & 2.81 & 2.85 & 3.00 & .0225 & 3.82 & $3>1$ \\
\hline Control $n=625$ & 3.43 & & \multicolumn{4}{|c|}{ No significant difference } & \\
\hline University participation $n=628$ & 2.32 & 1.67 & 2.45 & 2.65 & .0000 & 63.86 & $\begin{array}{l}3>1 \\
2>1\end{array}$ \\
\hline Professional participation $n=626$ & 2.75 & \multicolumn{6}{|c|}{ No significant differences } \\
\hline $\begin{array}{l}\text { Overall perceived participation } \\
(\text { sum } 26-31) n=614\end{array}$ & 17.18 & 16.12 & 16.96 & 17.86 & .0000 & 16.86 & $3>2>1$ \\
\hline Sum of $26-29$ (Factor 1$) n=618$ & 12.11 & 11.79 & 11.78 & 12.41 & .0111 & 4.54 & $3>2,1$ \\
\hline Sum of $30-31$ (Factor 2$) n=614$ & 5.07 & 4.33 & 5.15 & 5.47 & .0000 & 37.28 & $\begin{array}{l}3>1 \\
2>1\end{array}$ \\
\hline
\end{tabular}

* The mean values in this table result from the four-point scale used to measure perceived participation, where $1=$ not at all, $2=$ little, $3=$ moderately, $4=$ to a high degree.

groups in the following questions: "To what extent do you feel you exercise control over your day-to-day professional activities?" and "To what extent do you participate in library professional activities beyond your immediate institution?"

As a group, librarians scored highest in control over day-to-day activities (mean = 3.43) and lowest in participation in university academic affairs (mean $=2.32$ ).

\section{RELATIONSHIP OF PARTICIPATION TO SATISFACTION}

Correlations were run between the participation items (Questions 16 to 32) and all of the satisfaction items (Questions 33 to 53 and the sum of 33 to 53 ). To further quantify perceived participation for individual respondents a sum of scores on Questions 26 to 31 was calculated. Questions 16 to 20 , which dealt with actual participation, were coded to low, medium, and high values and summed for each respondent.

Librarians who scored high in actual participation (sum 16 to 20) also scored high in satisfaction. Similarly, librarians with high scores in perceived participation also scored high in satisfaction. In Tables 6 to 7 , as the significance levels approach 0 , the relationship is said to be strongest.

\section{RELATIONSHIP OF DEMOGRAPHICS TO JOB SATISFACTION}

The demographic features of the responding librarians were examined as they related to job satisfaction. Higher levels of benefits (eligibility for sabbaticals, tenure, research grants, or academic work year) were associated with higher levels of overall satisfaction. Greater benefits were also associated with greater satisfaction with their status, salary, opportunities for promotion or other advancement, and relationship with the university administration.

Higher salaries and more years as a professional librarian were associated with higher overall satisfaction and higher satisfaction with many of the items on the questionnaire.

Table 7 outlines the demographics of librarians related to overall satisfaction.

Although male librarians had higher levels of overall satisfaction when measured as a sum of all of the items, there was no difference between males and females in how they responded to the single item "overall satisfaction." Thus there is some support for previous studies that hypothesize greater job satisfaction among male librarians. 
TABLE 6

CORRELATIONS OF PARTICIPATION WITH OVERALL SATISFACTION

\begin{tabular}{lcc}
\hline & Question 54 & $\begin{array}{c}\text { Sum of Items } \\
33-53\end{array}$ \\
\hline Sum $16-20$ & $.1759^{*}$ & $.2366^{*}$ \\
Sum $26-29$ & $.5732^{*}$ & $.7165^{*}$ \\
Sum 30-31 & $.1815^{*}$ & $.3029^{*}$ \\
\hline
\end{tabular}

* Significance $<.01$

TABLE 7

RELATIONSHIP OF

DEMOGRAPHICS WITH OVERALL SATISFACTION

\begin{tabular}{lcc}
\hline & Question 54 & $\begin{array}{c}\text { Sum of } \\
\text { Items } \\
33-53\end{array}$ \\
\hline Status & .0589 & $.1858^{\dagger}$ \\
Rank & $.1128^{\dagger}$ & $.2116^{\dagger}$ \\
Sabbaticals & .0779 & $.1962^{+}$ \\
Tenure eligibility & $.1175^{\dagger}$ & $.1987^{\dagger}$ \\
Research grants & $.0866^{*}$ & $.15911^{+}$ \\
10-month work & $.1028^{*}$ & $.1903+$ \\
$\quad$ year or less & & \\
Tenured & $.1027^{*}$ & .0875 \\
Years as a librarian & $.0833^{*}$ & $.0969^{*}$ \\
Salary & $.1913^{\dagger}$ & $.2750^{\dagger}$ \\
Publication & .0168 & .0089 \\
$\quad$ requirements & & \\
Academic rank held & .0411 & $.1036^{*}$ \\
Department & .0701 & .0449 \\
Gender & .0257 & $.1030^{*}$ \\
Education & .0340 & .0382 \\
\hline
\end{tabular}

* Significance $<.05$

+ Significance $<.01$

The department or unit was not found to be related to job satisfaction.

\section{REGRESSION ANALYSIS}

A regression analysis was performed to find out which of the variables best predicts overall satisfaction. The sum of 33 to 53 was chosen for the regression analysis because it is considered the more reliable measure of overall satisfaction.

In a stepwise regression of all of the variables that correlated most highly with overall satisfaction, the extent to which librarians felt they are consulted, involved, informed, and in control of their own activities were the best predictors of overall satisfaction. When combined, these items predicted satisfaction more than any other. Salary was the next best predictor, followed by possession of academic rank.

\section{CONCLUSION}

Academic librarians with faculty status and rank are more satisfied than other librarians (nonfaculty or hybrid groups). They have higher levels of overall satisfaction and are more satisfied with many of the aspects of their positions. Academic rank is a determining factor in job satisfaction. Rank is most often held by librarians with faculty status. Only 13.4 percent of librarians reported having rank but not faculty status.

Librarians who feel more involved, consulted, informed, and more in control, are more satisfied. The key predictors of job satisfaction of academic librarians are perception of participation, salary, and possession of academic rank.

Perception of participation appears to be the crucial factor in job satisfaction. The best predictors of satisfaction were the extent to which the librarians perceive that they are involved in library planning and decision making, consulted about factors directly relating to their job responsibilities and work environment, informed about matters affecting the library, and in control of their own activities.

Librarians' perceptions of participation are not the same as actual measures of their participation. Librarians with faculty status and rank perceive themselves as more involved in library planning and decision making, more frequently consulted, better informed about matters affecting the library, and more involved in the university than nonfaculty or hybrid groups. Yet there are no differences in most categories of actual participation, such as amount of teaching, library and professional meetings attended, library association membership, or types of meeting structures. The only differences are in greater in- 
volvement with the university and more regular meetings of the library professional staff.

Presence of a formal library planning group, who served on it, and whether the recommendations were implemented, did not determine satisfaction. The model of library planning and decision making, explicitly whether it provided a low or high degree of participation by the librarians, also did not determine satisfaction. There were no differences among the groups in any of the above categories.

Although salary is less important than perception of participation, it is also a strong predictor of overall satisfaction. Findings on the relationship between income of academic librarians and satisfaction have varied in the past. While Mirfakhrai concludes there is no relationship, Chew found in an earlier study that income was related to satisfaction. ${ }^{14,15}$ Librarians with faculty status and rank are more highly paid and have greater benefits than librarians in other groups.

In general, academic librarians report above satisfactory levels of job satisfaction. Librarians are most satisfied with their relationships with library users and peers and with their assigned duties. They are least satisfied with their opportunities for promotion, other recognition for accomplishments, and their salary. This supports Mirfakhrai's findings that librarians were most satisfied with their relationships with coworkers and least satisfied with promotional opportunities. ${ }^{16}$ Mirfakhrai suggests librarians be encouraged to have input in planning and policy to combat the deficiency of promotion opportunities inherent in academic librarianship and the perception of librarianship as a "dead-end job." ${ }^{17} \mathrm{He}$ also found that experience and length of employment were negatively correlated with satisfaction, and suggested job rotation as a solution to the routine nature of the academic librarian's position. ${ }^{18}$ This finding was not upheld in this study, where years as a librarian were positively correlated with overall satisfaction.

In this study, it is obvious that faculty status and rank enhance the librarians' satisfaction with their jobs and percep- tions of their participation. Librarians with faculty status and rank have more overall satisfaction than other librarians and are more satisfied with most aspects of their jobs, including salary, opportunities for promotion or other advancement, and other recognition for accomplishments, which are generally weak areas of satisfaction in the profession. Hosel's theory of role-conflict resulting in reduced satisfaction levels for librarians with faculty status was not upheld in this research.

\section{Librarians with faculty status and rank have more overall satisfaction than other librarians and are more satisfied with most aspects of their jobs.}

The group with faculty status and rank contained significantly more librarians in advanced stages of their careers. In Group 3, 56 percent of the librarians had more than fifteen years of experience as a professional librarian, compared to 24 percent in Group 1 and 19 percent in Group 2. One interpretation is that librarians at this stage have advanced into the more desirable faculty positions.

Faculty status and rank may offer a solution to the routine nature of the profession. The expansion of one's responsibilities to include university-level involvement lends diversity and interest to the job. The opportunity for involvement in a changing array of academic, curricular, and personnel matters may help sustain the vitality and enthusiasm of librarians over the course of long careers.

There was no relation found between department or service area and satisfaction.Somesupport was found for previous studies that hypothesize gender differences in satisfaction. In this study, male librarians were significantly higher in the sum of all of the satisfaction items, one of the measures of overall satisfaction.

Support for the Marchant study is ambiguous because the librarian's perception of participation, rather than management's style, was the key predictor of satisfaction. However, there was a corre- 
lation between participative management style and satisfaction. Within the context of faculty status, perhaps it is the collegial relationship that fosters a sense of involvement and participation, rather than a recognized management style.

While debate about faculty status for librarians is unlikely to diminish in intensity as universities and colleges are pressured economically, one aspect of the debate which has been overlooked is the satisfaction of the librarians. Although job satisfaction is not linked in literature to increased productivity, there is a variety of important positive effects which have been demonstrated. ${ }^{19}$ These include positive effects on mental and physical health, longevity, and attitudes toward life and family. ${ }^{20}$

The findings on job satisfaction reported in this study provide information useful to administrators and librarians in their discussions of faculty status and rank for academic librarians.

\section{REFERENCES AND NOTES}

1. Harold V. Hosel, "Academic Librarians and Faculty Status: A Role Stress-Job Satisfaction Perspective," Journal of Library Administration, 5 (Fall 1984): 57-66.

2. Hano Johannsen and G. Terry Page, International Dictionary of Management, 4 th ed. (East Brunswick, N.J.: Nichols/GP Publishing, 1990), 218.

3. Maurice P. Marchant, The Effects of the Decision Making Process and Related Organizational Factors on Alternative Measures of Performance in University Libraries; A Dissertation. (Ann Arbor, Mich.: University Microfilms, 1970), 261.

4. Dale Susan Bengston and Dorothy Shields, "A Test of Marchant's Predictive Formulas Involving Job Satisfaction," Journal of Academic Librarianship 11 (May 1985): 88-92.

5. Susanne P. Wahba, "Job Satisfaction of Librarians: A Comparison between Men and Women," College \& Research Libraries 36 (Jan. 1975): 45-51; George P. D'Elia, "The Determinants of Job Satisfaction among Beginning Librarians," Library Quarterly 49, no.3 (1979): 283-302; Ilene F. Rockman, "Job Satisfaction among Faculty and Librarians: A Study of Gender, Autonomy, and Decision-Making Opportunities," Journal of Library Administration 5, no.3 (Fall 1984): 43-55.

6. Steven Seokho Chwe, "A Comparative Study of Job Satisfaction: Catalogers and Reference Librarians in University Libraries," Journal of Academic Librarianship 4, no.3 (1978): 139-43.

7. D'Elia, "Determinants of Job Satisfaction," 300.

8. Beverly P. Lynch and Jo Ann Verdin, "Job Satisfaction in Libraries: A Replication," Library Quarterly 57 (1987): 190-202.

9. Mohammed H. Mirfakhrai, "Correlates of Job Satisfaction among Academic Librarians in the United States," Journal of Library Administration 14, no.1 (1991): 117-31.

10. Leigh Estabrook, Chloe Bird, and Frederick L. Gilmore, "Job Satisfaction: Does Automation Make a Difference?" Journal of Library Administration 13, nos.1, 2 (1990): 175-93.

11. Janet Krompart and Clara DiFelice, "A Review of Faculty Status Surveys, 1971-1984," Journal of Academic Librarianship 13 (Mar. 1987): 14-18.

12. M. J. Norusis, SPSS Introductory Statistics: A Student Guide. (Chicago: SPSS, 1990), 321.

13. Norman H. Nie et al., SPSS Statistical Package for the Social Sciences, $2 \mathrm{~d}$ ed. (New York: McGraw-Hill, 1975), 427.

14. Mirfakhrai, "Correlates of Job Satisfaction," 123.

15. Chwe, "A Comparative Study of Job Satisfaction," 143.

16. Mirfakhrai, "Correlates of Job Satisfaction," 127.

17. Ibid., 129.

18. Ibid., 125, 130 .

19. Edwin A. Locke, "The Nature and Causes of Job Satisfaction," Handbook of Industrial and Organizational Psychology (Skokie, Ill.: Rand McNally, 1976) 1334.

20. Ibid. 


\section{APPENDIX \\ QUESTIONNAIRE ON JOB SATISFACTION, FACULTY STATUS, AND PROFESSIONAL PARTICIPATION}

This questionnaire is directed to full-time academic librarians. Please respond to each question below. Your contribution towards research in the area of job satisfaction of academic librarians is greatly appreciated. Your responses will be confidential. Return within two weeks to:

Professor Bonnie Horenstein

Adelphi University

Garden City, NY 11530

\section{BACKGROUND}

1. Do you have faculty status?

2. Do you have faculty rank?

3. Do you work as a librarian full-time?

$\begin{array}{ll}\text { yes } & \text { no } \\ \text { yes } & \text { no } \\ \text { yes } & \text { no }\end{array}$

4. Which of the following benefits are you eligible for? sabbaticals (paid or partly paid leaves) tenure research grants

10-month work year or less

$\begin{array}{ll}\text { yes } & \text { no } \\ \text { yes } & \text { no } \\ \text { yes } & \text { no } \\ \text { yes } & \text { no }\end{array}$

5. If you are eligible for tenure, are all full-time librarians at your institution eligible for tenure? yes no

6. If eligible, do you have tenure? yes no

7. If you have faculty status, do all librarians at your institution have faculty status?

8. Years as a professional librarian (include previous positions): - 0 -3 4-9 10-15 over 15

9. What is your present annual salary?

under 25,000

25,000-30,000
$30,000-35,000$

$35,000-40,000$
$40,000-45,000$ over 45,000

10. What best describes the publication requirement for promotion, tenure or other advancement of librarians at your institution? no publication required publishing encouraged some publication required substantial record of publication required other (please specify)

11. Your rank or status:

Instructor Professor Assistant Professor Other (please specify)

Associate Professor

12. Your department or service area: Acquisitions Automated Systems

Cataloging Other (please specify)

Serials

13. Your gender: male female

14. Your education (check as many as apply): M.L.S. Additional master's degree Ph.D. Other (please specify)

15. Your job title: 


\section{PARTICIPATION}

16. Approximately how many hours do you teach per year (formal group instructional sessions such as bibliographic lectures, library tours, etc.)?

none ${ }^{1-5}{ }^{6-15}{ }^{16-30}{ }^{31-45}$ over 45

17. Approximately how many hours per week do you attend meetings relating to the library? 3-5 more than 5

18. Approximately how many hours per week to you attend meetings relating to the university? 0 1-2 3-5 more than 5

19. In how many national, state, and/or local professional library associations are you currently a member? 0 1-3 more than 3

20. On the average how many professional meetings of national, state, and/or local associations do you attend each year?
0 1-3 4-7 over 8

21. Which model of library planning and decision-making best describes your library? little or no participation by librarians some consultation with librarians meaningful consultation with librarians high degree of participation by librarians none of the above

22. Does your library have regular meetings of the professional staff? yes no

23. Is there a library planning group, council, or other formal group that deals with academic matters of the library? yes no

24. If so, who serves on the planning group or council? librarians only mostly librarians and some administrators mostly administrators and some librarians administrators only (such as department heads group) other (please specify)

25. Are recommendations or decisions of the planning group generally implemented? yes no not applicable

\section{TO WHAT EXTENT?}

Please circle one response below.

Not at
all Little $\begin{gathered}\text { Moder- } \\ \text { ately }\end{gathered} \begin{gathered}\text { To a high } \\ \text { degree }\end{gathered}$

26. ... do you feel you are involved in library planning and decision-making?

$\begin{array}{llll}1 & 2 & 3 & 4\end{array}$

27. ... do you feel you are consulted about factors directly related to your job responsibilities or work environment?

\section{1}

28. ... do you feel you are informed by your administration about matters affecting the library? 
29. ... do you feel you exercise control over your day-to-day professional activities?

Not at Little
all $\begin{gathered}\text { Moder- } \\ \text { ately }\end{gathered} \quad \begin{gathered}\text { To a high } \\ \text { degree }\end{gathered}$

30. ... do you participate in institutional academic affairs (university senate, university committees, other university governance structures)?

31. ... do you participate in library professional activities beyond your immediate institution?

32. ... has technology changed your job responsibilities?

$\begin{array}{llll}1 & 2 & 3 & 4 \\ 1 & 2 & 3 & 4 \\ 1 & 2 & 3 & 4 \\ 1 & 2 & 3 & 4\end{array}$

\section{SATISFACTION}

How satisfied are you with each of the following aspects of your current position? Please circle the most correct response.

Unsatis-
factory $\begin{gathered}\text { Satis- } \\ \text { factory }\end{gathered} \quad \begin{gathered}\text { Highly } \\ \text { Satisfactory }\end{gathered}$

33. Assigned duties

34. Working conditions

35. Workload

36. Management's style

37. Relationship with peers

38. Relationship with library administration

39. Relationship with university administration

40. Relationship with library users

41. Status of librarians at your institution

42. Salary

4

43. Benefits (work year, tenure, tuition waiver, sabbaticals, etc.)

44. Opportunities for promotion or other advancement

45. Other recognition for accomplishments

$\begin{array}{lllll}1 & 2 & 3 & 4 & 5 \\ 1 & 2 & 3 & 4 & 5 \\ 1 & 2 & 3 & 4 & 5 \\ 1 & 2 & 3 & 4 & 5 \\ 1 & 2 & 3 & 4 & 5 \\ 1 & 2 & 3 & 4 & 5 \\ 1 & 2 & 3 & 4 & 5 \\ 1 & 2 & 3 & 4 & 5 \\ 1 & 2 & 3 & 4 & 5 \\ 1 & 2 & 3 & 4 & 5 \\ 1 & 2 & 3 & 4 & 5 \\ & & & & \\ 1 & 2 & 3 & 4 & 5 \\ 1 & 2 & 3 & 4 & 5 \\ & & & & \\ 1 & 2 & 3 & 4 & 5 \\ 1 & 2 & 3 & 4 & 5 \\ 1 & 2 & 3 & 4 & 5 \\ 1 & 2 & 3 & 4 & 5 \\ 1 & 2 & 3 & 4 & 5 \\ & & & & \\ 1 & 2 & 3 & 4 & 5 \\ 1 & 2 & 3 & 4 & 5 \\ 1 & 2 & 3 & 4 & 5 \\ 1 & 2 & 3 & 4 & 5\end{array}$

55. Your comments (attach a sheet as needed) : 


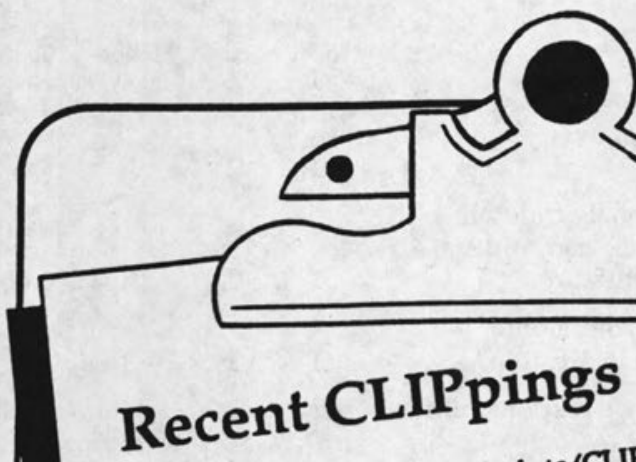

College Library Information Packets (CLIP Notes) collect data and sample documents for use by college and small und Notes are prepared establish or refine services Section.

Interlibrary Loan in College Libraries. CIP Note "16, compiled by Roxann Bustos.

Database Searching in College Llbraries. CIIP Note "15, compiled and written by Sarah Pederson. 124p. 0-8389-7651-4 1993

Utbraries. CIIP Note "14, compiled Audiovisual Policies in College Lolini.
by Kristine Brancolini. 521.95: ACRL member \$18.65 13. compiled by Patricia College Library Newsletters. Carthy Campbell. Smith Butcher and Susan McCarthy Cap. 0-8389-7445-7 1990 \$18.65: ACRL member \$15.3S 154p OPerformance Appraisal in Academic Libraries Cossistance of Mary $L$. compiled by Barbara Williams Jentins with 0-8389-7444-9 1990 Smalls. Collection Development Policies for College Libraries. CIIP Note Collection Development Policies for Colles Theresa Taborsky.
\#11, compiled by The $19899-7295-01989$
\$26.35: ACRL member \$21.94 175p. 0-8389

Association of College and Research Libraries

A division of the American Library Association c/o ALA Publishing Services, Order Department 50 East Huron Street • Chicago, Illinois 60611-2795 